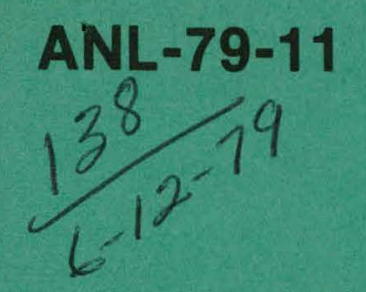

DR. 2699 ANL-79-11

\title{
THE STATUS AND DEVELOPMENT POTENTIAL OF PLATE-TYPE FUELS FOR RESEARCH AND TEST REACTORS
}

by

D. Stahl

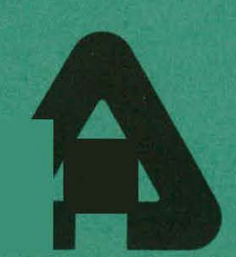

U ofC-AUA-USDOE

ARGONNE NATIONAL LABORATORY, ARGONNE, ILLINOIS

Prepared for the U. S. DEPARTMENT OF ENERGY

under Contract W-31-109-Eng-38 


\section{DISCLAIMER}

This report was prepared as an account of work sponsored by an agency of the United States Government. Neither the United States Government nor any agency Thereof, nor any of their employees, makes any warranty, express or implied, or assumes any legal liability or responsibility for the accuracy, completeness, or usefulness of any information, apparatus, product, or process disclosed, or represents that its use would not infringe privately owned rights. Reference herein to any specific commercial product, process, or service by trade name, trademark, manufacturer, or otherwise does not necessarily constitute or imply its endorsement, recommendation, or favoring by the United States Government or any agency thereof. The views and opinions of authors expressed herein do not necessarily state or reflect those of the United States Government or any agency thereof. 


\section{DISCLAIMER}

Portions of this document may be illegible in electronic image products. Images are produced from the best available original document. 
The facilities of Argonne National Laboratory are owned by the United States Government. Under the terms of a contract (W-31-109-Eng-38) among the U.S. Department of Energy, Argonne Universities Association and The University of Chicago, the University employs the staff and operates the Laboratory in accordance with policies and programs formulated, approved and reviewed by the Association.

\section{MEMBERS OF ARGONNE UNIVERSITIES ASSOCIATION}

The University of Arizona Carnegie-Mellon University Case Western Reserve University The University of Chicago University of Cincinnati Illinois Institute of Technology University of Illinois Indiana University The University of Iowa Iowa State University
The University of Kansas Kansas State University Loyola University of Chicago Marquette University The University of Michigan Michigan State University University of Minne sota University of Missouri Northwestern University University of Notre Dame
The Ohio State University Ohio University

The Pennsylvania State University Purdue University

Saint Louis University Southe rn Illinois University The University of Texas at Austin Washington University Wayne State University The University of Wisconsin-Madison

\section{NOTICE}

This report was prepared as an account of work sponsored by the United States Government. Neither the United States nor the United States Department of Energy, nor any of their employees, nor any of their contractors, subcontractors, or their employees, makes any warranty, express or implied, or assumes any legal liability or responsibility for the accuracy, completeness or usefulness of any information, apparatus, product or process disclosed, or represents that its use would not infringe privately-owned rights. Mention of commercial products, their manufacturers, or their suppliers in this publication does not imply or connote approval or disapproval of the product by Argonne National Laboratory or the U. S. Department of Energy.

Printed in the United States of America

Available from

National Technical Information Service

U. S. Department of Commerce 5285 Port Royal Road

Springfield, Virginia 22161

Price: Printed Copy $\$ 4.50$; Microfiche $\$ 3.00$ 


\section{ARGONNE NATIONAL LABORATORY \\ 9700 South Cass Avenue \\ Argonne, Illinois 60439}

THE STATUS AND DEVELOPMENT POTENTIAL OF PLATE-TYPE FUELS FOR RESEARCH AND TEST REACTORS

by

D. Stah 1

Materials Science Division

March 1979

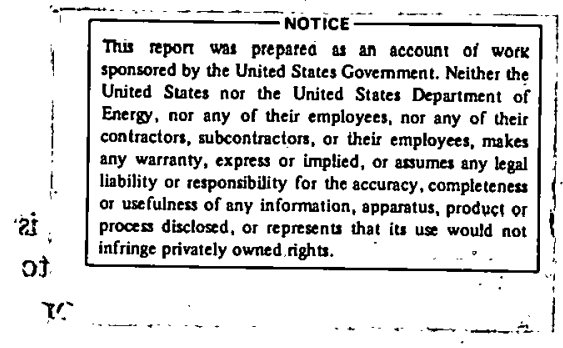


THIS PAGE

\section{WAS INTENTIONALLY \\ LEFT BLANK}


TABLE OF CONTENTS

$\underline{\text { Page }}$

ABSTRACT . . . . . . . . . . . . . . . . . . . . 6

I. TNTRODUCTTON . . . . . . . . . . . . . . . . . . 6

II. URANIUM-ALUMINUM ALLOY FUEL . . . . . . . . . . . . . . . 7

A. Introduction ..................... 7

B. Irradiation Performance . . . . . . . . . . . . . . 7

C. Development Potential .. . . . . . . . . . . . 8

III. ALUMINUM DISPERSION FUEL . . . . . . . . . . . . . . . . . 8

A. Introduction . . . . . . . . . . . . . . . 8

B. $\mathrm{UA1}_{\mathrm{x}}-\mathrm{A} 1$ Dispersions . . . . . . . . . . . . . . . . . 9

C. $\mathrm{U}_{3} \mathrm{O}_{8}^{-\mathrm{Al}}$ Dispersions . . . . . . . . . . . . . . . . 10

IV. POTENTIAL OF NEW FUEL TYPES . . . . . . . . . . . . . . 12

A. Introduction . . . . . . . . . . . . . . . . . 12

B. Corrosion Reslstance . . . . . . . . . . . . . . 12

C. Irradiation Performance ...... . . . . . . . . . 13

D. Development Potential ............... . 15

V. SUMMARY AND CONCLUSIONS . . . . . . . . . . . . . . . . 15

REFERENCES ............................... 17 
$\underline{\text { Page }}$

I. Uranium Density and Enrichment Reduction Potential of Candidate

Fuels for Research and Test Reactors . . . . . . . . . . 18

II. Fissile Dispersants . . . . . . . . . . . . . . . . 19

III. Properties of Fuels . . . . . . . . . . . . . . 20

T.TST OF FIGURES

$\underline{\text { Page }}$

1. Volume-Weight Relationships for Uranium Dispersion Fuels . . . . 21 
THE STATUS AND DEVELOPMENT POTENTIAL OF PLATE-TYPE FUELS FOR RESEARCH AND TEST REACTORS

by

D. Stahl

ABSTRACT

Recent II.S. Department of State action to restrict the shipment and use of highly enriched uranium for research and test reactors has renewed fuel development activity. The objective of these development activities is to increase. the total uranium loading in the fuel meat so that enrichment reduction can be accomplished without significant performance penalties. This report characterizes the status and the potential for development of the currently utilized platetype fuels for research and test reactors. The report also characterizes the newer high-density fuels which could be utilized in these reactors and indicates the impact of the utilization of both the new and current fuels on enrichment reduction.

\section{INTRODUCTION}

In the 1950s and 1960s, low-power research reactors were built worldwide which utilized Materlals Test Reactor (MTR)-type fuel elements containing $20 \%$ enriched uranium. [MTR elements consist of 17-19 curved plates within an $81 \times 76 \mathrm{~mm}(3.2 \times 3$ in.) box. Fuel length is $603 \mathrm{~mm}$ (23.75 in.).] However, the demand for higher speciflc power to provide higher neutron flux levels created a need for greater uranium-235 concentrations. Early difficulties in increasing uranium content led to the substitution of highly (90-93\%) enriched uranium in place of the $20 \%$ enriched fuel previously utilized. The highly enriched material also yielded other benefits including longer core residence time, higher specific reactivity and somewhat lower fuel-cycle cost. Highly enriched material then became readily available and was used for high-power reactors as well as low-power reactors where $20 \%$ enriched material would have sufficed. The trend toward higher and higher , specific power also led to the development of the dispersion-type fuels which utilized highly enriched uranium at a concentration of about $40 \mathrm{wt} . \%$.

In the 1970s, however, concerns were raised about the proliferation resistance of fuels and fuel cycles. As a consequence, the U.S. Department of State has recently prohibited the forelgn shipment of highly enriched materlal, except where prior contractual obligation or specific merit exists. This has impacted on the avallability and utilization of highly enriched uranium for research and test reactor fuel. It has also stimulated development programs on fuels with higher uranium content which would allow the use 
of uranium of lower enrichment. Fuel development programs are under way in the U.S., Canada, France, the Federal Republic of Germany (FRG), and Argentina.

The major fuel development activity in the U.S. is part of the Reduced Enrichment Research \& Test Reactors (RERTR) program which is managed by Argonne National Laboratory (ANL) for the Department of Energy. An objective of this program is to develop existing and new plate-type and, to some extent, rod-type research and test reactor fuels to their maximum uranium loading, which would make enrichment reduction possible. The enrichment-reduction potentials of the current and new fuels are shown in Table $I$. It is evident from the table that extensions of currently utilized fuels will permit enrichment reductions to $20 \%$ enriched fuel in low- and high-power research and test reaclurs, but that only the new fuels with higher uranium contents will permit such reductions for very high-power reactors. It is also evident from the table that enrichment reduction to $20 \%$ for low-power reactor fuels could be accomplished with existing cechnolugy.

The purpose of this report is to characterize the presently utilized fuels and the newer fuels as to uranium content and performance and to estimate the upper limits of uranium loading of these fuels for plate-type reactors.

\section{URANIUM-ALUMINUM ALLOY FUEL}

\section{A. Introduction}

Alloys of up to about $30 \mathrm{wt}$. \% uranium in aluminum can be easily fabricated by melting and casting techniques to yield uniform uranium distrihution, in the form of $\mathrm{UAl}_{3}$ and $\mathrm{UAl}_{4}$ precipitates in an essentially uranium-free:aluminum matrix. By proper casting and heat treating, the amount of the more brittle $\mathrm{UA}_{4}$ phase can be reduced. However, with in creasing uranium content, it becomes increasingly difficult to achieve,
uranium uniformity and the ductility of the alloy decreases as well.1,2

The ductility may be increased by suppressing rlie fun lid livin of the brittle $\mathrm{UAl}_{4}$ phase in favor of the more ductile $\mathrm{UAl}_{3}$ phase liruugh the use of certain ternary additions. Silicon has been successfully used as a suppressant. Additions of 0.8 and $3.0 \mathrm{wt} . \% \mathrm{Si}$ were found to completely suppress $\mathrm{UAl}_{4}$ formation in 20 and $48 \mathrm{wt}$. \% uranium-aluminum alloys, respectively. 3 other ternary additions which suppress $\mathrm{UAl}_{4}$ formation are $t i n$, germanium, zirconium, and titanium. ${ }^{2}$ The ternary alloy additions, however, complicate the standard reprocessing schemes. ${ }^{4}$ This difficulty, coupled with the introduction of the aluminum dispersion fuels, has curtalled further exploration of these systems.

\section{B. Irradiation Performance}

Fuel-plate assemblies with a meat (the uranium-containing portion of the fuel) composed of a U-A1 alloy with 18-22 wt. \% U have been extensively 
tested in the MTR and the Experimental Test Reactor (ETR). ${ }^{1}$ The average burnup of the fuel has exceeded $25 \%$ with peaks of $1.8 \times 10^{21} \mathrm{fissions} / \mathrm{cm}^{3}$. Experimental assemblies have been run to $75 \%$ burnup with no deleterious effect. 5 Swelling appears to be linearly related to irradiation exposure, with a value of $6.38 \% \Delta \mathrm{V} / \mathrm{V}$ per $10^{21} \mathrm{fissions} / \mathrm{cm}^{3}$. Unmodified U-Al fuels have performed we11 at concentrations of 24 and $30 \mathrm{wt}$. \% uranium. For. example, the 50-MW General Electric Test Reactor has been ut1lizing U-A1 fuel meat containing $30.5 \mathrm{wt}$. \% uranium. 6 The core average fuel-burnup limit is $50 \%$, with a maximum of $2.0 \times 10^{21}$ fissions $/ \mathrm{cm}^{3}$ (Ref. 7).

Experimental irradiations were also performed with U-AI alloys containing ternary additions. Small plates containing $48 \mathrm{wt} . \% \mathrm{U}$ and $3 \mathrm{wt}$. $\%$ Si were successfully irradiated to burnups of $83 \%\left(7.50 \times 10^{20}\right.$ fissions $\left./ \mathrm{cm}^{3}\right) .^{8}$ Standard plates containing up to $50 \mathrm{wt}$. \% uranium with additions of s111con and tin were irradiated to large burnups $\left(85 \%\right.$ or $1.0 \times 10^{21}$ fissions $/ \mathrm{cm}^{3}$ ) under MTR conditions without dimensional distortion. ${ }^{9}$

C. Development Potential

As noted above, U-Al alloy plates have been produced which contained up to $50 \mathrm{wt}$. \% uranium plus small ternary additions to suppress the formation of the brittle $\mathrm{UA}_{4}$ phase. Recent development activity at NUKEM in the FRG and at Savannah River Laboratory (SRL) has been directed toward increasing the uranium concentration to 40 and to perhaps $45 \mathrm{wt}$. \% without ternary additions by proper casting and hot-working techniques.10,11 Because of its limited potential as indicated in Table $\mathrm{I}, \mathrm{U}-\mathrm{Al}$ alloy fuel was not included in the RERTR program.

III. ALUMINUM DISPERSION FUEL

A. Introduction

As noted in Section II, the difficulty in achieving uniform fuel distribution in $\mathrm{U}-\mathrm{Al}$ alloy fuels led to development of configurations in wh1ch fuel parteles were dispersed in a metallic matrix. The diepersion approach provides a distinct separation of the fissile fuel particle and the metal matrix so that their desirable properties are retained. The metal matrix material must possess the following properties: high formability, high thermal conductivity, high corrosion and radiation resistance, and low thermal-neutron cross section. Among others, alloys of $\mathrm{Al}, \mathrm{Be}, \mathrm{Mg}, \mathrm{Nb}$ and $\mathrm{Zr}$, and stainless steel have been employed as matrix materials. $12^{\mathrm{B}}$

The fuel particles must possess high radiation and corrosion resistance and high uranium density and must be compatible with the matrix material. The particles should also possess some hot formability when present in high concentrations. The particle size should be large enough $(>100 \mu \mathrm{m})$ so that fission-product damage is concentrated in the particle. Particle spacing should be large enough so that damage zones, which surround the particles, do not link up. Porosity, which is usually associated with the particles, also providco come swelling accommodation. A number of fissile 
compounds are given in Table II. The theoretical uranium content per unit volume of dispersed phase, its relation to the density of uranium metal, and the melting points of the compounds, which provide a relative indication of stability, have also been included in the table.

Considerable work was performed with. $\mathrm{UO}_{2}$ dispersed in stainless steel or aluminum because of its stability and high uranium concentration. The 1955 Geneva Conference Reactor (GCR) used an $\mathrm{UO}_{2}-\mathrm{Al}$ fuel. Great difficulty was experienced during manufacture of the GCR fuel elements because of abnormal dimens lonal growth during elevated-temperature fabrication procedures. The growth of the fuel plates was traced to volume changes accompanying the reaction of $\mathrm{UO}_{2}$ and aluminum. The reaction reached 90 to $100 \%$ completion in $10 \mathrm{~h}$ at $600^{\circ} \mathrm{C}$ in $52 \mathrm{wt} . \% \mathrm{UO}_{2}$ fuel plates. 14 Fortunately, experimenters at ANL discovered that $\mathrm{U}_{3} \mathrm{O}_{8}$ was more stable than $\mathrm{UO}_{2}$ with aluminum and recomended its use. 15 Later experiments at Oak Ridge National Laboratory (ORNL) confirmed that the reaction of $\mathrm{U}_{3} \mathrm{O}_{8}$ with aluminum was murh slnwer at the temperatures needed for fabrication. 16 It was shown that $3000 \mathrm{~h}$ were required for complete reaction at $600^{\circ} \mathrm{C} .17^{\mathrm{C}}$ Fuel plates could, therefore, be fabricated from $\mathrm{U}_{3} \mathrm{O}_{8}$ and aluminum with relatively little difficulty arising from dimensional changes due to a reaction between the components. This process, however, leads to a fuel element which retains the potential for an exothermic (thermite*) reaction between the components.

The reactions of $\mathrm{U}_{3} \mathrm{Si}, \mathrm{U}_{3} \mathrm{Si}_{2}$, $\mathrm{UC}$, and $\mathrm{UC}_{2}$ with aluminum were, also evaluated, in $620^{\circ} \mathrm{C}$ tests lasting up to $48 \mathrm{~h}$. No reaction occurred with $\mathrm{UC}_{2}$; however, $\mathrm{U}_{3} \mathrm{Si}, \mathrm{U}_{3} \mathrm{Si}_{2}$, and $\mathrm{UC}$ were found to react with aluminum, but at a slower rate than $\mathrm{UO}_{2} \cdot{ }^{13}$ Studies on aluminides ${ }^{18}$ showed that $\mathrm{UA}_{2}$ reacts rapidly, and $\mathrm{UA}_{3}$ reacts slowly, with aluminum to form the stable compound $\mathrm{UA}_{4}$, which undergoes no further reaction with A1. A mixture of aluminides, designated $U A I_{x}$ but compositionally close to $\mathrm{UAl}_{3}$, will therefore react with aluminum in the reactor, but at a slow rate. The stable $\mathrm{UAl}_{4}$ is not used directly, since it is very brittle and not easily formable with present plate-fucl technology.

B. UA1 $\mathrm{x}-\mathrm{A} 1$ Dispersions

1. Irradiation Performance. Dispersions of $\mathrm{UAl}_{\mathrm{X}}$ in aluminum have performed satisfactorily in the ETR and Advanced Test Reactor at 22 and 41 wt. \% uranium contents, respectively.1,19 In these tests, prototypic elements are exposed to average burnup levels of $30 \%\left(0.8 \times 10^{21}\right.$ fissions $\left./ \mathrm{cm}^{3}\right)$ and peak levels of $290 \%\left(\sim 2.3 \times 10^{21}\right.$ fissions $\left./ \mathrm{cm}^{3}\right) .19,20$ Experimental p1ates have performed successfully after irradiation in the MTR, ETR, High Flux Isotope Reactor (HFIR), and FR? (Karlsruhe) under a wide variety of conditions with the maximum burnup closely approaching total depletion of the uranium-235 ( $2.8 \times 10^{21}$ fissions $\left./ \mathrm{cm}^{3}\right) .1,9,19,21$ Swelling rates were generally about one half that of U-Al alloy at about $3 \% \Delta V / V$ per $10^{2 I}$ fissions/ $\mathrm{cm}^{3}$ (Ref. 1). However, for the MTR experiments, which utilized slightly lower temperatures and water pressures, swelling rates were found to approach

*A thermite reaction is one that involves the ignition of aluminum powder with an oxide to rapidly produce a great deal of heat. 
that of the U-Al alloy. It is postulated that under these conditions, the process of in-pile densification, which reduces swelling, is impeded. For most irradiations, swelling was roughly linear with burnup to the maximum value tested. The exception was the FR2 (Karlsruhe) data, which showed an increase in swelling rate to about $12 \% \Delta V / V$ per $10^{21}$ fissions $/ \mathrm{cm}^{3}$ after a burnup of $40 \%\left(21.5 \times 10^{21}\right.$ fisstons $\left./ \mathrm{cm}^{3}\right) .21$

2. Development Potential. Potential exists for increasing the uranium loading of $\mathrm{UAl}_{\mathrm{X}}-\mathrm{Al}$ dispersion fuels. In the past, experimental loadings of only $45 \mathrm{wt}$. \% uranium were fabricated. 20 However, it is anticipated that $50 \mathrm{wt}$. \% uranium loadings, equivalent to about 50 vol \% $\mathrm{UAl}_{\mathrm{X}}$, can be eas1ly fabricated as part of a development program. Th1s $11 \mathrm{mit}$ may possibly be extended to 55-60 wt. \% uranium; however, careful control of fabrication parameters will be necessary to prevent enlargement of the ends of the fuel-meat cores (dogboning) and to maintain uniform meat thickness, width, and uranium distribution.

\section{C. $\quad \mathrm{U}_{3} \mathrm{O}_{8}-\mathrm{A} 1$ Dispersions}

1. Irradiation Performance. The HFIR at ORNL utilizes aluminum-clad fuel plates with fuel meats consisting of a dispersion of uranium oxide $\left(\mathrm{U}_{3} \mathrm{O}_{8}\right)$ in aluminum. The maximum fuel loading in the meat of these fuel plates is $\sim 40 \mathrm{wt} . \%$ uranium $\left(\sim 47 \mathrm{wt} . \% \mathrm{U}_{3} \mathrm{O}_{8}\right)$; the meat thickness varies from about 250 to $760 \mu \mathrm{m}$ (about 0.010 to $0.030 \mathrm{in.)}$ ). The average burnup of the fissile atoms is $31 \%\left(0.9 \times 10^{21}\right.$ fissions $\left./ \mathrm{cm}^{3}\right)$, with peaks of $265 \%$ ( $21.9 \times$ $10^{21}$ fissions $\left./ \mathrm{cm}^{3}\right) .22$ Experimental plates have experienced burnups of $\sim 75 \%$ ( $2.1 \times 10^{21}$ fissions $/ \mathrm{cm}^{3}$ ) without failure or gross dimensional change. As part of the $\mathrm{U}_{3} \mathrm{O}_{8}$ dispersion-fuel development program for HFIR and the Puerto Rico Nuclear Center Reactor, test samples were made, irradiated, and evaluated at ORNL. 8,23 The fuel loading was 55 wt. \% uranium ( 65 wt. $\% \mathrm{U}_{3} \mathrm{O}_{8}$ ) in the meat, which was $\sim 610 \mu \mathrm{m}$ ( $20.024 \mathrm{in}$.) in thickness. Short plate-type specimens were found to be dimensionally stable after a burnup of $7.7 \times 10^{20}$ fissions $/ \mathrm{cm}^{3}$ (>90\% U $\mathrm{U}^{235}$ depletion). A full-size MTR-type element was found to be dimensionally stable after a burnup of $\sim 4 \times 10^{20}$ fissions $/ \mathrm{cm}^{3}$ ( $250 \%$ $\mathrm{U}^{235}$ depletion). 8 Thus, $55 \mathrm{wt}$. \% uranium represents the present maximum fuel loading of $\mathrm{U}_{3} \mathrm{O}_{8}$ dispersion-type aluminum plate fuel.

Related recent development activity at SRL on $\mathrm{U}_{3} \mathrm{O}_{8}-\mathrm{Al}$ dispersionfueled tubes has indicated that $48 \mathrm{wt}$. \% uranium (58 wt. \% $\mathrm{U}_{3} \mathrm{O}_{8}$ ) loadings have performed well after 141 irradiation days. 11

2. Development Potential. The potential for development of higher uranium loadings for $\mathrm{U}_{3} \mathrm{O}_{8}$ dispersion-type aluminum plate fuel does exist. As part of the $\mathrm{U}_{3} \mathrm{O}_{8}$ dispersion-fuel development program at ORNL for HFIR and at SRL, test samples were made that contained up to $100 \mathrm{wt} . \% \mathrm{U}_{3} \mathrm{O}_{8}$ in the meat. 11,22 As expected, for loadings greater than about $60 \mathrm{wt} . \%$ uranium (about $70 \mathrm{wt} . \% \mathrm{U}_{3} \mathrm{O}_{8}$ ), depending on void content. the continuous phase of the dispersions changed from aluminum to $\mathrm{U}_{3} \mathrm{O}_{8}$. However, all cold-pressed $\mathrm{U}_{3} \mathrm{O}_{8}-\mathrm{Al}$ dispersions exhibited sufficient green strength after compacting to permit some handling. All of the plate fuel appeared to roll-clad satisfactorily, as was evident from the absence of internal cracks. However, for the tubular fuel elements, high extrueion ratios led to overheating which 
produced a thermite reaction between $\mathrm{U}_{3} \mathrm{O}_{8}$ and aluminum. The meat thickness and extrusion ratio are being reduced to eliminate this problem. 11

In addition to the potential for a thermite reaction, technical issues which must be addressed to increase the uranium loading beyond $55 \mathrm{wt} . \%$ include: adequate control of cladding thickness, dogboning, a continuous aluminum phase in the meat, uranium homogeneity, and fuel behavior under long-term irradiation (i.e., unacceptable swelling and shrinking). of perhaps critical importance is the maintenance of a continuous aluminum phase that will facilitate heat flow out of the meat. Based on simple geometric considerations, a uranium loading of about 60 vol.\%, which is about 70 wt. \% (about $80 \mathrm{wt} . \% \mathrm{U}_{3} \mathrm{O}_{8}$ ), appears to be the theoretical limit for maintenance of the continuous aluminum phase in a $\mathrm{U}_{3} \mathrm{O}_{8}-\mathrm{Al}$ dispersion with $\mathrm{U}_{3} \mathrm{O}_{8}$ spheres (see F1g. 1). Slightly higher loadings may be possible with control of particle shape and size distribution.

3. Thermite-reaction Concerns. As noted above, the potential for a thermite reaction must be evaluated as part of the safety analysis. Both off-normal and transient effects must be considered. Fortunately, some data are available under both of these conditions.

Fleming and Johnson heated cold-pressed pellets of mixtures of $\mathrm{U}_{3} \mathrm{O}_{8}$ and aluminum at $33^{\circ} \mathrm{C} / \mathrm{min} .24$ At a composition range of $65-75 \mathrm{wt} . \% \mathrm{U}_{3} \mathrm{O}_{8}$, violent exothermic reactions occurred between 900 and $1100^{\circ} \mathrm{C}$ with a peak energy release of $1.2 \mathrm{MW}-\mathrm{s} / \mathrm{kg}$ fuel. This reaction was also studied by workers at ANL using various compositions, pretreatments, environments, and particle size distributions. 25,26 However, a slow heat-up rate $\left(25^{\circ} \mathrm{C} / \mathrm{min}\right)$ was used in these tests, and the violent reactions reported by Fleming and Johnson were not duplicated; only temperature excursions to a maximum of $1300^{\circ} \mathrm{C}$ were observed. Similar results were obtained for specimens inserted into a furnace at $1250^{\circ} \mathrm{C}$. In contrast, for specimens which were sintered at $600^{\circ} \mathrm{C}$ after pressing, vinlent reactions were observed with compositiono of 75 and $85 \mathrm{wt}$. $\% \mathrm{U}_{3} \mathrm{O}_{8}$. Thus, the reaction rate ran he strongly influenced by the preconditioning of the compacts.

Large-scale tests with full-size elements were performed by SRL for $\leq 57$ wt. \% U $\mathrm{U}_{3} \mathrm{O}_{\mathrm{g}} \mathrm{Al}$ cores. 11 It was found that the maximum filel temperature. was $1370^{\circ} \mathrm{C}$, only $370^{\circ} \mathrm{C}$ above the furnace temperature. Thus the heat of reaction was not an important energy source for these fuel elements.

Transient-reactor (TREAT) experiments on $\mathrm{U}_{3} \mathrm{O}_{8}-\mathrm{Al}$ HFIR fuel plates were performed by ANL. 27 The tests simulated nuclear excursion accidents in a water-cooled reactor. Specimens of U-A. fuel were inoluded for comparison. The major conclusions were that the $\mathrm{U}_{3} \mathrm{O}_{8}-\mathrm{Al}$ specimens retained their shape up to $1400^{\circ} \mathrm{C}$ (a significantly higher temperature than that observed for $\mathrm{U}-\mathrm{Al}$ fue1) and that the exothermic reaction was not an important energy source. 
IV. POTENTIAL OF NEW FUEL TYPES

A. Introduction

Although the development of increased uranium loadings in current research-reactor fuel types, if successful, will allow many research reactors to utilize lower-enrichment uranium in the fuel, there will still be several research and test reactors which cannot be converted to the use of low-enrichment uranium fuel. These are the reactors that are already operating with highly enriched fuel at the highest uranium loadings currently qualified. Also, these are in general the more advanced (higher power-density) and more highly utilized research reactors which are designed for extralong reactivity-core 1 ife.

Thus, for new research reactors, and for replacement fuels in the higher power-density research reactors, one option is to develop a different research-reactor fuel specifically designed for high uranium loadings. This option could allow the research reactor to convert to low-enrichment uranium fuel with a minimum impact on the core design or operation as compared with other options such as complete core modification or decommissioning. Development of this fuel option also provides a backup if the planned developments based on current fuel do not work out.

Several advanced fuel types have been and are being studied. The properties of some of these fuels are shown in Table III (taken from Ref. 28). Not all of them are compatible with a water-cooled research reactor environment. The candidate fuel materials possess much higher uranium densities than the currently utilized dispersion fuels, which possess a uranium loading of only $1.7 \mathrm{~g} / \mathrm{cm}^{3}$. The corrosion resistance, irradiation performance, and development potential of some of these candidates fuels"is given in the following sections. These materials could be utilized alone or even as a dispersant since their uranium densities, as listed in Table II, are much greater than that of $\mathrm{UAl}_{\mathrm{x}}$ or $\mathrm{U}_{3} \mathrm{O}_{8} \cdot$

\section{B. Corrosion Resistance}

Metallic uranium alloys and compounds were extensively investigated in the U.S., principally at ANL, Battelle; Knolls Atomic Power Laboratory, and Westinghouse, in the late 1940s and the 1950s as fuels for light-water reactors. Severa1 thorough reviews of the subject have been published. ${ }^{29}, 30$ These investigations focused on alloying to improve the poor corrosion resistance of uranium and to ameliorate the anisotropic growth problem inherent in the unalloyed material. In these early efforts, almost every metallic element was alloyed with uranium in an attempt to produce a fuel which would be resistant to high-temperature water. The alloys with good to moderate corrosion resistance fall structurally into two groups: metastable gamma alloys and distorted alpha alloys. The former are produced by quenching from $800-1000^{\circ} \mathrm{C}$. Molybdenum and niobium compositions in the range of 7 to $15 \mathrm{wt}$. \% and 6 to $20 \mathrm{wt}$. \%, respectively, have been studied. Corrosion resistance was dependent on heat-treatment conditions, with molybdenum supertor to niobium. The alpha-alloy group consisted mainly of alloys with zirconium (up to $10 \mathrm{wt}$. \%) or niobium (up to $6 \mathrm{wt} . \%$ ) and ternary alloys 
containing both these elements. However, when these alloys, in wrought form, were heat treated or aged for maximum corrosion resistance, they exhibited poor dimensional stability under irradiation.

It is also possible to provide corrosion resistance by the formation of Intermetallic compounds. $\mathrm{U}_{3} \mathrm{Si}$ has been studied because it possesses reasonable ductility and a moderately high decomposition point. With proper heat treatment, this compound is nearly as corrosion resistant as the best uranium-molybdenum alloy. 31 More recent work on this alloy system by the Atomic Energy of Canada Limited (AECL) has shown that the addition of $1-1 / 2 \%$ aluminum substantially increases the corrosion resistance of the fuel. 32

Another approach to the problem of providing corrosion resistance was developed at SRL. 33 Corrosion resistance can be provided by a diffusion bond between an intermediate layer and both the fue 1 and rladding. The fuel was bonded to the aluminum cladding by utilizing an Al-Si dip-canning process on early fuel elements and an electroplated nickel layer on later fuel elements. Both methods were followed by a hot die-sizing process to form the diffusion bond. This technique substantially reduces the exposure of the fuel to hot water in the event the cladding is penetrated. A diffusion bond between a uranium-zirconium. alloy and the Zircaloy-2 cladding, created by coextrusion, was also found to provide excellent corrosion resistance. 30

of the ceramic compounds listed in Table III, only $\mathrm{UD}_{2}$ possesses chemical inertness and resistance to high-temperature water.

\section{Irradiation Performance}

Uranlimim-molybdenum alloys generally exhibit satisfa:tory irradiation behavior. In early work, the $I I-1, n$ wt: \% Mo alloy wac ohown to be stable tu at least 5 at. \% burnup exrept for abnormal swelling of some samples operaled at $335-390^{\circ} \mathrm{C}$, possibly due to plastic flow effects near the alpha-bcta transition temperature. 30 The corrosion resistance of these materials was relatively good, since the gamma phase was stabilized by the irradiation. Similar behavior was found in more recent work at SRL on alloys containing lower Mo concentrations and 0.1 wt. \% si.1ir.nn. 34 Swelling ratee of $2-4 \% /$ at. $\%$ burnup were found after Irradiations of 9000 and $12000 \mathrm{MWd} / \mathrm{t}$ up to $600^{\circ} \mathrm{C}$ maximum fuel temperature, again with the exception of abnormal swelling at $\sim 400^{\circ} \mathrm{C}$. The 1rradiacton behavior of uranium-niobium alloys was found to be similar to that of uranium-molybdenum. 30 However, additions of $4-6 \mathrm{wt} . \%$ of zirconium to $\mathrm{U}-10 \mathrm{wt}$. \% $\mathrm{Nb}$ raised the abnormal swelling temperature to above $4.50^{\circ} \mathrm{C}$,

The irradiation behavior of uranium-zirconium and uranium-zirconiumniobium alloys genera11y has been less favorable. 30,34 However, additions of carbon were found to greatly modify swelling behavior in low-burnup tests. 30 Good irradiation performance has been obtained with a U-5 wt. \% Fs alloy (where the fissium is made up of the mixture of fission products expected in recycled fuel) to burnups exceeding 10 at. $\%$ in the EBR-II. 35 However, these cast and heat-treated rods are bonded to the cladding with sodium; this provides volume for $\sim 30 \%$ swelling up to about 4 at. \% burnup, after which the cladding can easily restrain the spongy fuel. 
Ongoing experiments at SRL with very small additions of $\mathrm{Cr}, \mathrm{Al}, \mathrm{Si}$, $\mathrm{Fe}$, and Mo (either separately or in combination) to uranium have produced interesting results. 34 Most of these alloys were quenched from $725^{\circ} \mathrm{C}$, then irradiated to 9000 and $13000 \mathrm{MWd} / \mathrm{t}$ at various temperatures ranging from 200 to $600^{\circ} \mathrm{C}$. Swelling rates of $3-4 \% /$ at. \% burnup were found for alloys containing 800-1150 ppm Al + Si at temperatures below the swelling threshold of $350^{\circ} \mathrm{C}$. Alloys containing the above $\mathrm{Al}+\mathrm{S} 1$ concentrations were further improved by the addition of $250-350 \mathrm{ppm} \mathrm{Fe}, 200 \mathrm{ppm} \mathrm{Cr}$, and $1000 \mathrm{ppm} \mathrm{Mo.}$ An alloy containing $800^{\circ} \mathrm{ppm} \mathrm{Al,} 350 \mathrm{ppm} \mathrm{Si}, 350 \mathrm{ppm} \mathrm{Fe}$, and $1000 \mathrm{ppm}$ Mo was found to be stable to approximately $425^{\circ} \mathrm{C}$.

The early irradiations of $\mathrm{U}_{3} \mathrm{Si}$ fuel material produced mixed reAtomic Power Division were found to have increased in both length and diameter. Several. samples were bowed and all exhibited cracks, blisters and bands. However, in tests performed by ANL, both cast and extruded samples exhibited good irradiation stability. In recent experiments at AECL, $\mathbf{U}_{3} \mathrm{Si}$ and aluminum-modified $\mathrm{U}_{3} \mathrm{Si}$ showed excellent irradiation performance. 36,37 Diameter increases for Zircaloy-clad $\mathrm{U}_{3} \mathrm{Si}$ in the form of annular fue1 rods were less than $1 \%$ after $10,000 \mathrm{MWd} / \mathrm{t}$ and about $1.2 \%$ after 19,000 $\mathrm{MWd} / \mathrm{t}$ at a maximum temperature of about $500-600^{\circ} \mathrm{C}$. With the addition of 1.5 and 2.4 wt. \% aluminum, diameter increases were reduced slightly and, as noted earlier, the corrosion resistance of the alloy fuel was improved.

Despite its poor thermal conductivity, $\mathrm{UO}_{2}$ performs well since it can be operated at steady-state central temperatures approaching its melting point. $38 \mathrm{UO}_{2}$ was used as the fuel material for this country's first prototype power reactors - the Shippingport pressurized water reactor (PWR) and the Vallecitos boiling water reactor (BWR) - which were built in the late 1950s. However, metal fuels were utilized in the early experimental reactors (the Ship Thermal Reactior developed by ANL, Westinghouse, and the Naval Reactors Division - USAEC; and the Experimental Boiling Water Reactor developed by. ANL). 39 The shift to oxide fuel oçurred because the behavior of metal alloy fuels was found to be inadequate. 38

The reference fuel for both the PWR and the $\mathrm{BWR}$ is still $\mathrm{UO}_{2}$ in the form of pellets of $293 \%$ theoretical density. Satisfactory performance has been obtalned at burnups of over $40,000 \mathrm{MWd} / \mathrm{t} .40,41$ This led to the consideration of oxide fuel for liquid metal-cooled fast breeder reactors and to the development of an information data base on oxide fuels for this application. ${ }^{42}$ A similar document is available for light water reactor oxide-fuel behavior. $43 \mathrm{UO}_{2}$ fuel rods which contain $\sim 5 \%$ enriched uranium have also been used in the PULSTAR reactore.

Morc recently, the French have 11tilized UO $\mathrm{O}_{2}$ wafers (caramels) in a compartmentalized Zircaloy cladding arrangement for plate-type reactors. 44 The plates have performed well to a maximum burnup of $30,000 \mathrm{MWd} / \mathrm{t}$. The French design is similar in concept to that employed in the second core of Shippingport, which utilized $\mathrm{UO}_{2}-\mathrm{ZrO}_{2}$ as fuel and $\mathrm{UO}_{2}$ in the blanket. As part of the development of the $\mathrm{UO}_{2}$ plates for the blanket, Westinghouse performed high-temperature irradiations to burnups as high as $140,000 \mathrm{MWd} / \mathrm{t}$ 
(4 $\times 10^{21}$ fission $\left./ \mathrm{cm}^{3}\right) .45$ However, plate failures occurred at a burnup as low as $20,000 \mathrm{MWd} / \mathrm{t}\left(20.6 \times 10^{21} \mathrm{fission} / \mathrm{cm}^{3}\right)$ as a result of fission-gas release.

\section{Development Potential}

The data presented above suggest that $\mathrm{U}_{3} \mathrm{Si}$, probably modified with aluminum, has the greatest potential for providing the necessary uranium density and irradiation performance levels. Uranium-molybdenum alloys appear to be the second choice, with $\mathrm{UO}_{2}$ third. $\mathrm{UO}_{2}$ would have to be fabricated in the form of very thin members because of its poor thermal conductivity. Interestingly, the French have chosen U-Mo alloys as a backup for their $\mathrm{UO}_{2}$ caramel fue. .45

"It is likely that $\Pi_{3} S i$ can bo utilised ao a dispersdil I." 1 1u!nluum, provided that the positive volume change upon reaction to form $\mathrm{UAl}_{3}$ can be reduced or slowed by alloy addition. As shown in Fig. $1, \mathrm{U}_{3} \mathrm{Si}$ provides a much higher uranium weight fraction than does an equal volume of $\mathrm{U}_{3} \mathrm{O}_{8}$ or $\mathrm{UAl}_{\mathrm{x}}$. For example, an expected volume-fraction range of $0.5-0.7$ would yield uranium weight fractions of about $0.8-0.9$, as indicated in Table $I$. Thus an alloy addition would not greatly reduce the uranium loading. The use of an aluminum dispersion would mean that present dispersion fuel-meat technology could be utilized, rather than some advanced technology which might require cladding with Zircaloy or some other material which is stiffer than aluminum. However, the greater density difference between $U_{3} S i$ and aluminum would necessitate care in the blending of powders to maintain uniform fuelparticle distribution.

Another potential problem with $\mathrm{U}_{3} \mathrm{Si}_{i}$ concerns reprocessing. Siliron in some weight-fraction ranges has. been shown to interfere with phase separation in the extraction column. ${ }^{4}$ A study is under way at ANL to detcrmine whether the aqueous process can be successfully modified or whether a suitable nonaqueous method can be utilized to accomplish the reprocessing of plate-type fuels containing $\mathrm{U}_{3} \mathrm{Si}$.

\section{SUMMARY AND CONCLUSIONS}

The current emphasis on the conversion of plate-type research and test reactor fuel from fully enriched uranium to less than $20 \%$ enrichment or to some intermediate enrichment, perhaps $45 \%$, has stimulated the development of more highly uranium-loaded fuels. The development effort has been logically divided into two areas: the extension of currently utilized fuels to their maximum uranium loading, and the development of new high-denstty fuels.

The uranium-density and enrichment-reduction potential of current fuels was summarized in Table I. It is anticipated that U-Al alloy fuel which contains 40-45 wt. \% uranium can be developed; this loading will permit reductions to less than $20 \%$ enrichment for low-power reactors, but will permit reductions to only intermediate enrichment for other reactors. 
Aluminide and $\mathrm{U}_{3} \mathrm{O}_{8}$ dispersion fuels could reach uranium densities as high as 60 and $70 \mathrm{wt}$. \%, respectively, which would make possible the use of less than $20 \%$-enriched uranium in high-power reactors. This assumes that dispersions contalning 60 vol \% of the dispersed fuel phase are possible. For both of these materials, fuel fabricators and developers have stated 47 that $\sim 55$ vol \% will be the maximum loading possible as a result of development efforts. If only 50 vol \% dispersions are possible, which is a more likely outcome, then the aluminide dispersion might not permit the conversion of high-power reactors without some modification of the fuel-meat thickness and element geometry. This may be true for $\mathrm{U}_{3} \mathrm{O}_{8}$ dispersions as we11. Little or no highburnup experience exists for these extensions of currently utilized fuels; in contrast, considerable positive experience exists for the lower uranium loadings. This suggests that if uniform dispersions of highly loaded fuel can be successfully fabricated, there is a strong likelihood that they will exhibit satisfactory Irradiation behavior.

For the new high-density fuels, a nearly opposite situation exists. Very little low-temperature, high-burnup irradiation experience has been obtained. For $\mathrm{U}_{3} \mathrm{Si}$ and U-Mo alloys, the maximum burnup was less than $20,000 \mathrm{MWd} / \mathrm{t}$, while for $\mathrm{UO}_{2}$ plates, the maximum burnup was less than 30,000 $\mathrm{MWd} / \mathrm{t}$. As far as uranium loading is concerned, these materials are more than adequate, and dispersions may be utilized to take advantage of existing dispersion-fuel technology. However, the compatibllity of the fuel compound with the matrix must be assessed. $\mathrm{U}_{3} \mathrm{Si}$, for example, must be stabilized so that its slow in-pile reaction with aluminum does not yield large volume increases. Such dispersions with 50 or more volume percent of dispersed fuel would allow conversion of even the very high-power reactors.

Thus it is likely that the fuel development effort now under way will provide the technical means of reducing enrichment in research and test reactors. Extensions of currently utilized fuels should allow the conversion of low- and.high-power reactors and the new high-density fuels should allow the conversion of very high-power reactors. 


\section{REFERENCES}

1. G. W. Gibson, The Development of Powdered Uranium-Aluminide Compounds for Use as Nuclear Reactor Fuels, Idaho Nuclear Corporation Report IN-1133.(Dec. 1967).

2. J. E. Cunningham, R. J. Beaver, W. C. Thurber, and R. C. Waugh, Fuel Dispersions in Aluminum-base Elements for Research Reactors, Fue1 Elements Conference, Paris, Nov. 1957, TID-7546, Bk. 1, pp. 269-297 (March 1958).

3. R. 0. Williams, Metallurgy Division Quarterly Progress Report-Period Ending October 31, 1950, Oak Ridge National Laboratory Report ORNL-910, Pp. 9-11 (1951).

4. B. E. Paige, G. W. Glbson, and K. L. Rohde, The Effect of Silicon on Fabrication and Reprocessing of Aluminum Alloy Reactor Fuels, Idaho Nuclear corporation Keport IN-1194 (Nov. 1968).

5. J. R. Huffman, Technical Quarter1y Report-Fourth Quarter 1953, Phillips Petroleum Company Report IDO-16153, pp. 27-2.8 (Fph. 195/).

6. GETR Safety Analysis Report, Vallecitos Nuclear Center Report NEDO-12522,. (June 1977).

7. W. A. Erwin, General Electric Nuclear Energy Division, Pleasanton, CA, personal communication (March 1978).

8. A. E. Richt, C. F. Leitten, Jr., and R. J. Beaver, Radiation Performance: and Induced. Transformations in Aluminum-Base Fuels, Research Reactor Fuel Element Conferense, Gatifinhirg, TN, Sept. 1962, TID 7642, Bk, 2, pp. 469488 .

9. W. C. Francis, G. W. Gibson, and W. P. Scarrah, Some Results of Uranium Aluminum Irradiations at the MTR/ETR, Ibid., pp. 444-468.

10. H. W. Hasse1, NUKEM GmbH, Hanau, Federal. Republic of Germany, personal communication, (May 1978).

11. G. F. Merz, R. L. Frontroth, and J. R. Hester, Savannah River Laboratory, Aiken, SC, personal communication (Apri1 19.78).

12. C. E. Weber and H. H. Hirsch, Dispersion-Type Fuel E1.ements, Proc. Int'1. Conf. on Peaceful Uses of Atomic. Energy, Geneva, Vo1. 9, pp. 196-202 (1955).

13. F. A. Rough and A. A. Bauer, Constitution of Iranium and Thorium Alloye, Battelle Memorial Institute Report, BMI-1300 (June 1958).

14. M. L. Picklesimer, The Reaction of $\mathrm{UO}_{2}$ with Aluminum, Oak Ridge National Laboratory Report CF-56-80135 (Aug. 1956). 
15. J. H. Handwerk, R. A. Noland, and D. E. Walker, Uranium-Oxide-Containing Fuel Element Composition and Method of Making Same, U.S. Patent 2,805,473 (Sept. 1957).

16. R. J. Beaver and J. E. Cunningham, Recent Developments in Aluminum-Base Fuel Elements for Research Reactors, Oak Ridge National Laboratory Report TID-7559 (Aug. 1959).

17. R. C. Waugh, J. E. Cunningham, and R. J: Beaver, Aluminum-Uranium Oxide Reaction, Uranium Oxide: Properties and Nuclear Applications, J. Belle, Ed., USAEC, pp. 364-371 (1961).

18. M. J. Graber, W. F. Zelezny, and G. W. Gibson, Annual Progress Report on Reäctor Fuels and Materials Development for FY 1964, Phillips Petroleum Company Report IDO-17037 (Nov. 1964).

19. "Safety Analysis-Utilization of Intermetallic Uranium Aluminide and Uranium Oxide Cermet Fuel Cores in the Ford Nuclear Reactor," Univ. of . Mich., Ann Arbor, License Submittal R-28, June 1977 (Rev. Oct. 1977).

20. W. C. Francis, EG\&G Idaho, Inc., personal communication (June 1978).

21. W. Dienst, S. Nazaré, and Thümmler, F., Irradiation Behavior of UA1 $-\mathrm{Al}$ Dispersion Fuels for Thermal High Flux Reactors, J. Nucl. Mater. 64, 1-13 (1977).

22. M. M. Martin, Oak Ridge National Laboratory, Oak Ridge, TN, personal communication (April 1978).

23. M. M. Martin, A. E. Richt, and W. R. Martin, Irradiation Behavior of Aluminum-Base Fuel Dispersions, Oak Ridge National Laboratory Report ORNL-4856 (May 1973).

24. J. D. Fleming and J. W. Johnson, Aluminum-U ${ }_{3} 0_{8}$ Exothermic Reactions, Nucleonics 21.(5), 84-87 (1963).

25. L. Baker, J. D. Bingle, R. Warcha1, and C. Barners; Aluminum- $\mathrm{U}_{3} \mathrm{O}_{8}$ Thermite Reaction, ANL/CEN Semiannual Report for July-December 1963, Argonne National Laboratory Report ANL-6800, pp. 390-402 (1964).

26. L. Baker and J. D. Bingle, Aluminum- $\mathrm{U}_{3} \mathrm{O}_{8}$ Thermite Reaction, ANL/CEN Semiannual Report for January-June 1964, Argonne National Laboratory Report ANL-6900, pp. 298-303 (i964).

27. R. 0. Ivins and F. J. Testa, Studies with Aluminum- $\mathrm{U}_{3} \mathrm{O}_{8}$ Cermet Fuel in TREAT, ANL/CEN Semiannual Report for July-December 1965, Argonne Nationa1 Laboratory Report ANL-7125, pp. 163-170 (1966).

28. M. T. Simnad and J. P. Howe, Materlals for Nuclear Fission Power Reactor Technology, General Atomic Corporation Report GA-A14012 (December 1976).

29. H. S. Kalish et a1., Uranium Alloys, Reactor Handbook, Second Edition, Interscience Publ., New York, pp. 147-210 (1969). 
30. A. Boltax, Behavior of Fissionable Material Under Irradiation, Nuclear Reactor Fuel Elements-Metallurgy, and Fabrication, Interscience Publ., New York, pp. 292-361 (1962).

31. J. E. Draley, Problems of Fuel Element Corrosion in Water, Nuclear Fue1 Elements, Reinhold Pub1., New York, pp. 314-328 (1959).

32. M. A. Fereday et al., Irradiation Behavior of Uranium-Silicide Fuels at High Power, Trans. Am. Nucl. Soc. 14(2), 569-570 (1971).

33. W. R. McDonnel and E. F. Sturcken, Development of High-Performance Uranium-Metal Fuels for Savannah River Reactors, Nuc1. Technol. 26, 420-429 (1975).

34. W. R. McDonnel and W. N. Rankin, Swelling Resistance of Iranium A1loys at High Irradiation Exposures, Savannah River Laboratory Report DP-MS-71-1.

35. B. R. Seide1 and R. Einziger, In-Reactor Cladding Breach of EBR-II Driver Fuel Elements, presented at Int'1. Mtg.'on Breeder Structura1 Materials, Scottsdale, Arizona, June 1977.

36. M. A. Fereday et al., The Irradiation Behavior of $U_{3} S i$ Elements to High Burnup, Chalk River Nuclear Laboratories Report AECL-4058 (March 1974).

37. M. A. Fereday et a1., Irradiation Behavior of a Corrosion Resistant U-Si-Al Fuel Alloy, Chalk River Nuclear Laboratories Report AECL-5028 (March 1975).

38. R. B. Holden, Ceramic Fue1 E1ements, Gordon and Breach, Now York (1966).

39. M. T. Simnad, Fuel Element Experience in Nurlear Power Reactore, Gordon and Breach, New York (1971).

40. Current Status and Future Technical and Economic Potential of Light Water Reactors, USAEC Report WASH-1082 (March 1968).

41. Operating Experience with Therma1 Fuels, Proc. Joint Topical Meeting on Commercial Fuel Technology Today, Toronto, Canada, April 28-30, 1975.

42. Nuclear Systems Materials Handbook, TID-26666, Hanford Engineering Development Laboratory, Richland, Washingtonn.

43. MATPRO-Version 09, A Handbook of Materials Properties for Use in the Analysis of Light Water Reactor Fuel Rod Behavior; TREE-NUREG-1005, EG\&G Idaho.

44. J. P. Schwartz, Uranium Dioxide Caramel Fuel, presented at Int1. Conf. on Nuclear Non-Proliferation and Safeguards, AIF, New York, Oct. 22-25, 1978. 
45. T. D. Anderson, Effects of HIgh Burnup on Bulk UO 2 Fuel Elements, Nucl. Saf. 6(2), 164-69 (1964).

46. M. Rapin, CEA, France, personal communication (May 1978).

47. Proc. Int1. Mtg. of Research Reactor Fuel Designers, Developers, and Fabricators, Argonne National Laboratory, Nov. 9-10, 1978, in press. 
TABLE I. Urariun Density and Enrichment Reduction Potential of Candidate Fuels for Research and Test Reactors.

\begin{tabular}{|c|c|c|c|c|c|}
\hline \multirow{2}{*}{ Fuel Type } & \multirow{2}{*}{$\begin{array}{l}\text { Near-term } \\
\text { Uranium Loading, } \\
\text { wt. } \%\left(\mathrm{~g} / \mathrm{cm}^{3}\right)\end{array}$} & \multirow{2}{*}{$\begin{array}{l}\text { Long-term } \\
\text { Uranium Loading, } \\
\text { wt. } \%\left(\mathrm{~g} / \mathrm{cm}^{3}\right)\end{array}$} & \multicolumn{3}{|c|}{$\begin{array}{l}\text { Near-T } 2 \text { rm/Long-Term Enrichment- } \\
\text { reduction Potential, \% }\end{array}$} \\
\hline & & & $\begin{array}{l}\text { Low-power } \\
\text { Reactors }\end{array}$ & $\begin{array}{l}\text { High-power } \\
\text { Reactors }\end{array}$ & $\begin{array}{l}\text { Very High-power } \\
\text { Reactors }\end{array}$ \\
\hline U-A1 Alloy & $30(1.1)$ & $40-45(1.6-1.9)$ & $20 / 20$ & $70 / 45$ & $93 / 45$ \\
\hline $\mathrm{UAl}_{\mathrm{x}}-\mathrm{Al}$ & $42(1.7)$ & $50-60(2.2-3.0)$ & $20 / 20$ & $45 / 20$ & $93 / 45$ \\
\hline $\mathrm{U}_{3} \mathrm{O}_{8}^{-\mathrm{Al}}$ & $42(1.7)$ & $60-70(3.1-4.2)$ & $20 / 20$ & $45 / 20$ & $93 / 45$ \\
\hline $\mathrm{UO}_{2}$ Caramel Fuel & & $85 .(9.6)$ & 20 & 20 & $20^{a}$ \\
\hline $\mathrm{U}_{3} \mathrm{Si}, \mathrm{U}_{3} \mathrm{Si}-\mathrm{A} 1$ & $\cdot$ & $80-90(7.0-13.4)$ & 20 & 20 & 20 \\
\hline $\mathrm{U}-10 \mathrm{Mo}$ & . & $90(14.8)$ & 20 & 20 & 20 \\
\hline
\end{tabular}

${ }^{a}$ For very high-fower reactors, $\mathrm{UO}_{2}$ would have to be fabricated in very thin sections to provide proper heat removal. 
TABLE II. Fissile Dispersants ${ }^{\mathrm{a}}$

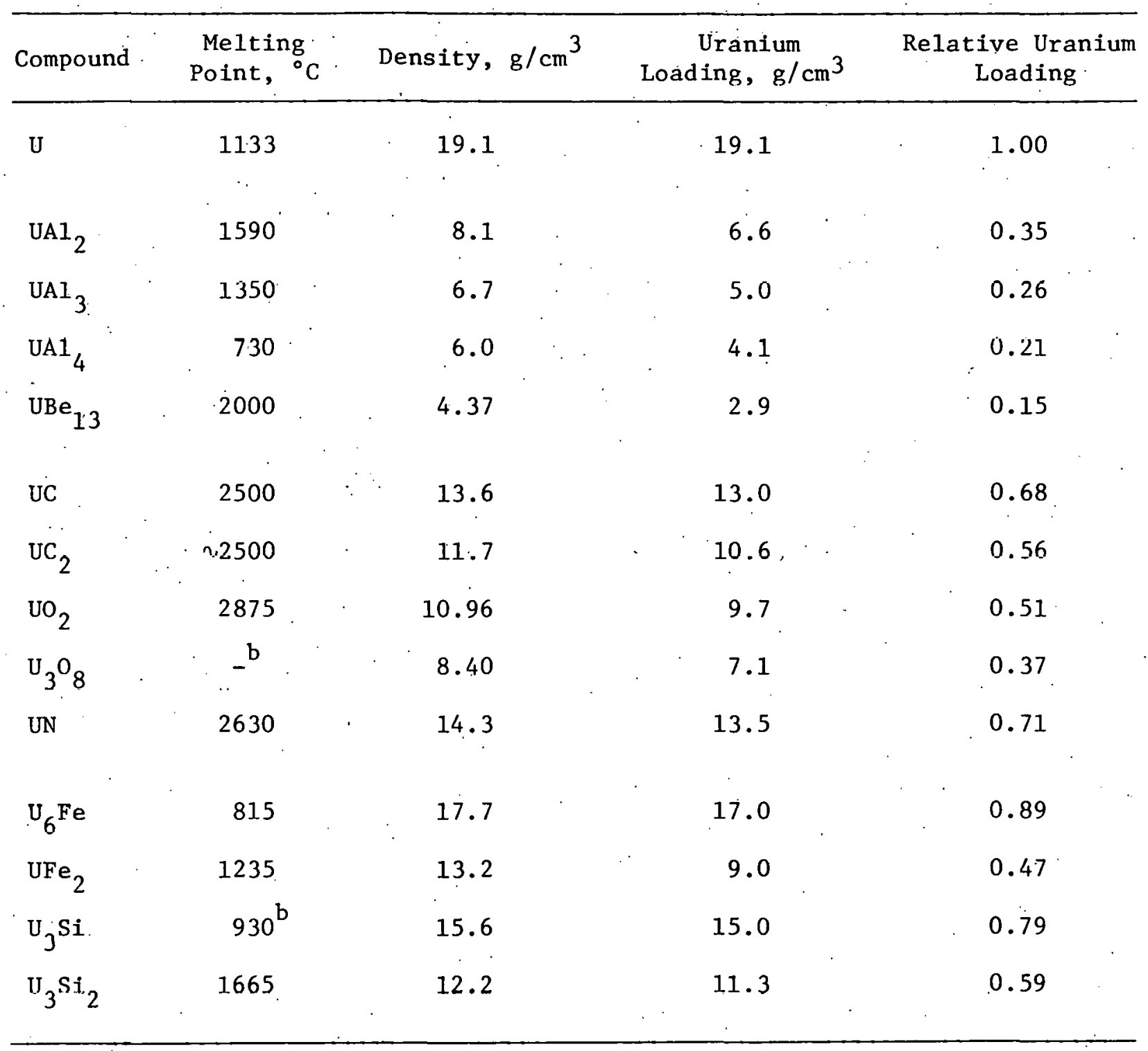

${ }^{a}$ From Ref. 13.

$b_{\text {Decomposes. }}$ 
TABLE III. Properties of Fuels

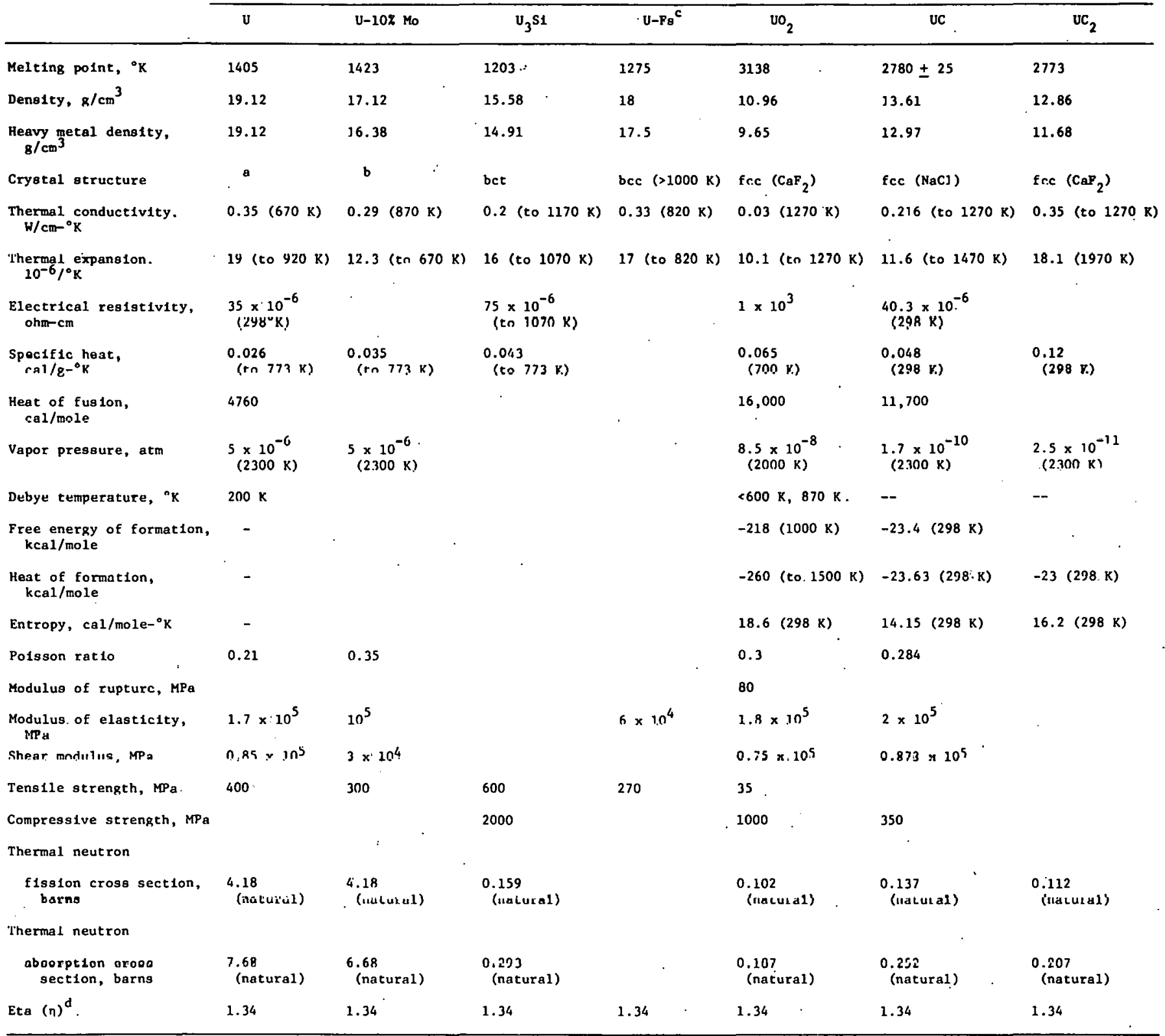

OOrthorhomblc $\left(<9^{\circ} 36^{\circ} \mathrm{K}\right)$, tetragonal $\left(936-1043^{\circ} \mathrm{K}\right)$, body-centered cub1c $\left(>1043^{\circ} \mathrm{K}\right)$.

brthorhomble plus tetragonal $\left(<838^{\circ} \mathrm{K}\right)$, body-centered cublc $\left(>838^{\circ} \mathrm{K}\right)$.

${ }^{c} \mathrm{U}$ containing $5 \%$ fissium $(0.22 \% \mathrm{zr}+2.5 \% \mathrm{Mo}+1.5 \% \mathrm{Ru}+0.3 \% \mathrm{Rh}+0.5 \% \mathrm{Pd})$. U-5\% fissium 1s bec above $1000^{\circ} \mathrm{K}$, bcc + monoclinic $\mathrm{U}_{2} \mathrm{Ru}$ between $825^{\circ} \mathrm{K}$ and $1000^{\circ} \mathrm{K}$, and bec $+\mathrm{U}_{2} \mathrm{Ru}+$ tetragonal below $825^{\circ} \mathrm{K}$.

${ }^{d}$ Number of fission neutrons released per neutron absorbed. 


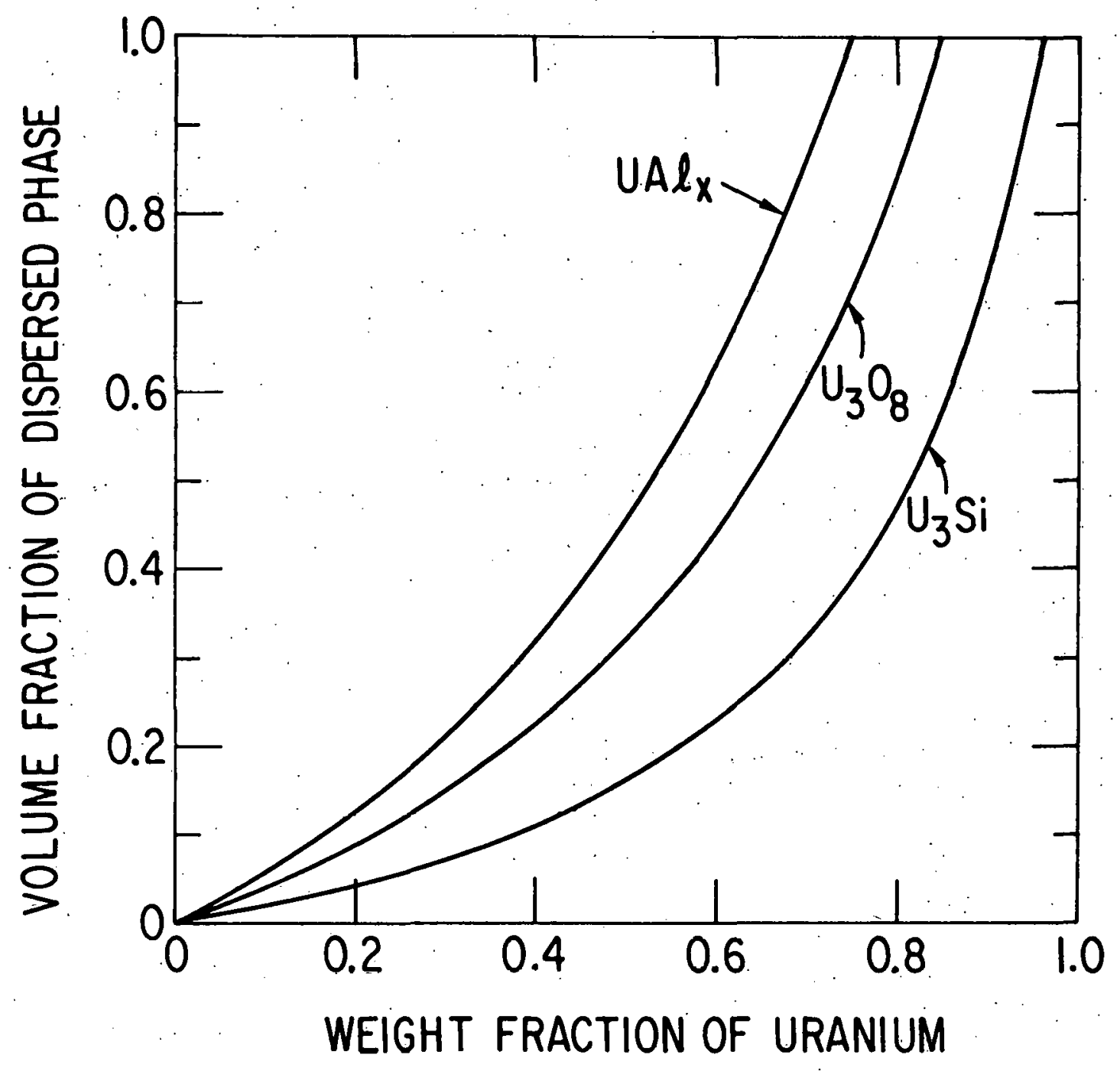

Fig. 1. Volume-Weight Relationships for Uranium Dispersion Fuels. 
Distribution for ANL-79-11

Interna1:

J. A. Kyger

R. Avery

L. Burris

D. W. Cisse1

S. A. Davis

B. R. T. Frost

R. J. Teunis

C. E. Till

R. S. Zeno

R. W. Weeks

F. Y. Fradin

J. H. Kittel

J. T. Venard

L. T. Lloyd

F. A. Niohole

J. F. Schumar

E. Stefanski (4)

A. Trave11i (20)

J. E. Matos

J. L. Snelgrove
T. H. Blewitt

M. B. Brodsky

T. F. Kassner

S. Greenberg

A. G. Hins

K. L. Merkle

L. A. Neimark

D. J. Lam

M. H. Mueller

N. L. Peterson

R. B. Poeppe1

K. J. Reimann

$J$ Rest

W. J. Shack

R. W. Slege 1

D. Stah1 (8)

H. R. Thresh

A. P. L. Turner

H. Weldersicli

M. M. Bretscher
T. A. Daly

L. R. Dates

J. F. de Paz

R. F. Domagala

K. E. Freese

E. F. Groh.

H. Henryson

V. Z. Jankus

L. R. Kelman

H. Komoriya

F. E. Levert

E. M. Pennington

B. C. Reynolds

R. M. St. Pierre

W. L. Woodruff

F. L. Yaggee

A. B. Krisciunas

ANL Contract File

ANL Libraries $(7)$

TIS Files (6)

\section{External:}

DOE-TIC, for distribution per UC-80 (138)

Manager, Chicago Operations and Regional office, DOE

Chief, Office of Patent Counsel, DOE-CORO

Director, Reactor Programs Div., DOE-CORO

Director, CORO-INEL, DOE

Chief, Fuel Cycle Branch, NPD-DOE (2)

President, Argonne Universities Association

Materials Science Division Review Committee:

E. A. Aitken, General Electric Co., Sunnyvale

G. S. Anse11, Rensselaer Polytechnic Institute

R. W. Balluffi, Massachusetts Inst. Technology

R. J. Birgeneau, Massachusetts Inst. l'echnology.

S. L. Cooper, U. Wisconsin

C. Laird, U. Pennsylvania

M. T. Simnad, General Atomic Company

C. T. Tomizuka, U. Arizona

A. R. C. Westwood, Martin Marietta Labs.

A. P. 01son, Science Applications, Inc., Uakbrook, I11.

D. R. MacFarlane, ETA Engineering, Inc., Westmont, I11. 